\title{
Antitumor and anti-invasive effects of diverse new macrocyclic lactones, alkylolides and alkenylolides, and their enhancement by hyperthermia
}

\author{
HIROSHI TANAKA ${ }^{1}$, KATSUHIRO KAGEYAMA ${ }^{1}$, KUMIKO KUSUMOTO ${ }^{2}$, \\ RYOKO ASADA ${ }^{1}$ and NOBUHIKO MIWA ${ }^{3}$ \\ ${ }^{1}$ Osaka Butsuryo College, Sakai, Osaka 593-8328; ${ }^{2}$ Department of Health Science, International Buddhist University, \\ Habikino, Osaka 583-8501; ${ }^{3}$ Laboratory of Cell-Death Control BioTechnology, Faculty of Life and \\ Environmental Sciences, Prefectural University of Hiroshima, Shobara, Hiroshima 727-0023, Japan
}

Received April 18, 2007; Accepted July 12, 2007

\begin{abstract}
Alkylolides and alkenylolides of 198-254 Da such as hexadecan-16-olide and 9-hexadecen-16-olide were chemically synthesized in the present study as new macrocyclic lactones that are structurally different from widespread natural macrocyclic lactones including bryostatin (887 Da) and rhizoxin $(613 \mathrm{Da})$, and were investigated for antitumor activity to Ehrlich ascites tumor cells by mitochondrial dehydroganase-based WST-1 assay and dye-exclusion assay. Of the alkylolides having 12, 15 or 16 carbon-atoms (D12:0, P15:0 or H16:0) and alkenylolides having 15 or 16 carbonatoms with a double bond (P15:1 or H16:1), H16:0 was the most carcinostatic when administered at $37^{\circ} \mathrm{C}$ for $20 \mathrm{~h}$, with cell deformation and microvillus disappearance as detected by scanning electron microscopy. The carcinostatic activity was increased markedly for H16:0 and P15:0 when the administration period was prolonged to $72 \mathrm{~h}$, but was not enhanced by intramolecular introduction of a double bond for P15:1 or H16:1. Hyperthermia at $42^{\circ} \mathrm{C}$ for 30 min additively intensified the carcinostatic activity for H16:0 and P15:0, but scarcely for D12:0, and intensified the alkenyloides P15:1 and H16:1 only upon the subsequent 72-h treatment. Invasion of human fibrosarcoma HT-1080 cells through the reconstituted basement membrane was inhibited by alkyland alkenylolides even after the short-term exposure at $25 \mu \mathrm{M}$ for $3 \mathrm{~h}$ without diminishing the cell viability. H16:0 also exhibited the most inhibitory activity to tumor invasion in addition to the highest carcinostatic activity. Both inhibitions were promoted by combination with hyperthermia. Thus diverse alkyl-/alkenylolides, may be potent multi-applicable anticancer agents in terms of either dual inhibitory activities
\end{abstract}

Correspondence to: Dr Katsuhiro Kageyama, Osaka Butsuryo College, 3-33, Otorikita-cho, Nishi-ku, Sakai, Osaka 593-8328, Japan E-mail: kageyama@butsuryo.ac.jp

Key words: marocyclic lactone, alkylolide, alkenylolide, antitumor activity, hyperthermia, tumor invasion against both tumor progression and invasion or hyperthermiacombined therapy.

\section{Introduction}

Natural macrocyclic lactones, such as bryostatin isolated from the marine bryozoan Bugula neritina (1) and rhizoxin from the plant pathogenic fungus Rhizopus chinensis (2) or rhizopus sp No.F-360 (3) have been reported to be potent anticancer agents in some preclinical murine models. Bryostatin exhibits antitumor activity against leukemia and melanoma $(4,5)$, and rhizoxin against MH134 hepatoma (3). These macrocyclic lactones, i.e. bryostatin and rhizoxin are natural compounds showing a molecular weight of 887 and $613 \mathrm{Da}$ $(1,2)$.

In the present study antitumor effects of alkylolides and alkenylolides, the lower molecular weight (198-254) of new macrocyclic lactones chemically synthesized, in contrast to the higher molecular weight $(>600)$ of natural macrocyclic lactones, were examined from diverse viewpoints: i) enhanced carcinostasis in combination with hyperthermia, which inhibit tumor cell growth (6-8), and subsequent long-term culture, ii) morphological cellular degeneration, iii) anti-invasive activity as shown by diminished cell penetration through the reconstituted basement membrane.

Carcinostatic effect was evaluated with a decrease in mitochondrial dehydrogenase activity reflecting survival rate of cells as measured by WST-1 assay $(9,10)$ and with a decrease in viable cells observed morphologically by trypan blue dye exclusion assay (11). Morphological cellular degeneration was observed by scanning electron microscopy (12). The ability of antitumor agents to inhibit tumor cell invasion into blood vessels prior to tumor metastasis is essential for clinic application (13).

\section{Materials and methods}

Materials. Alkylolides and alkenylolides were kindly provided by Soda Aromatic Co., Ltd. (Tokyo), were dissolved in ethanol, and stored frozen as test solutions. Details are shown in Table I. 
Table I. Alkylolides and alkenylolides, macrocyclic lactones examined and their chemical structures.
Chemical name
Chemical formula
Abbreviation
Chemical structure

Dodecan-12-olide

Pentadecan-15-olide

Hexadecan-16-olide

10-Pentadecen-15-olide
$\mathrm{C}_{12} \mathrm{H}_{22} \mathrm{O}_{2}$

$\mathrm{C}_{15} \mathrm{H}_{28} \mathrm{O}_{2}$

$\mathrm{C}_{16} \mathrm{H}_{30} \mathrm{O}_{2}$

$\mathrm{C}_{15} \mathrm{H}_{26} \mathrm{O}_{2}$

$\mathrm{C}_{16} \mathrm{H}_{28} \mathrm{O}_{2}$
D12:0

P15:0

$\mathrm{H} 16: 0$

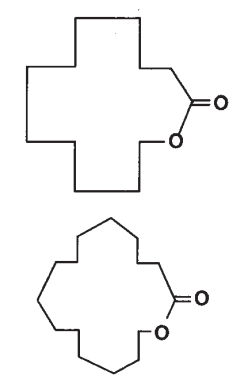

P15:1
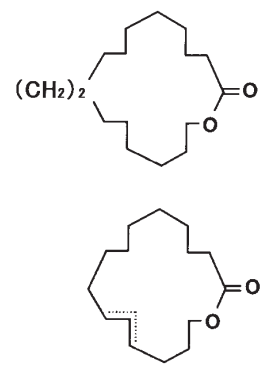

$\mathrm{H} 16: 1$
Cell viability assay. Viability of cells was measured using two different methods: i) the redox indicator dye WST-1 (9) (Cell Counting Kit, Dojin Chemicals, Kumamoto, Japan) is more chromic according to mitochondrial dehydrogenase activity. The cultured cell suspension was transferred into a sampling tube and was centrifuged, the supernatant was completely removed from the tube, $110 \mu \mathrm{l}$ of WST-1 (8\%) per well was added to the cell precipitate, then suspended and transferred into each well of a 96-well microplate. After incubation at $37^{\circ} \mathrm{C}$ for $1 \mathrm{~h}$, the resultant formazan was determined by measuring the absorption at $450 \mathrm{~nm}$ with a plate reader (Benchmark, Bio-Rad Laboratories, CA). ii) Dye exclusion assay was performed as follows: the cultured cell suspension was treated as described above. Freshly prepared trypan blue dye solution in MEM (0.20\%) of $60 \mu 1$ was added to $60 \mu \mathrm{l}$ of cell suspension, and microscopic counts of living (unstained) and dead (stained) cells were conducted on a hemocytometer $(8,11)$.

Morphological observation of cells. Cells were treated in the presence of $\mathrm{H} 16: 0$ alkylolide at 37 or $42^{\circ} \mathrm{C}$ for $30 \mathrm{~min}$ and cultured for $20 \mathrm{~h}$ in a $\mathrm{CO}_{2}$ incubator. Specimens were fixed with $2.5 \%$ glutaraldehyde and $2 \%$ paraformaldehyde in a $0.1 \mathrm{M}$ phosphate buffer ( $\mathrm{pH}$ 7.2) at room temperature for $2 \mathrm{~h}$. The specimens were then placed in $0.1 \mathrm{M}$ phosphate buffer overnight, and postfixed with $1 \%$ osmium tetroxide for $2 \mathrm{~h}$, then washed in re-distilled water (RWD) followed by for 20 or $72 \mathrm{~h}$. 
dehydration through a graded series of ethanol. For scanning electronic microscopic (SEM) study, samples were transferred to tert-butyl alcohol, and dried using a freeze drier (ES-2030, Hitachi, Tokyo), sputter-coated with gold-palladium, and examined in a Hitachi S-2460N scanning electronic microscope operated at $5 \mathrm{kV}$ (12).

Tumor cell invasion assay. To each well of a 24-well cuture plate, $500 \mu 1$ of $10 \%$ FBS-MEM was added, and then a Chemotaxicell (Invasion Chamber, Kurabo Industries, Ltd., Osaka) having a porous resin membrane (pores with an $8-\mu \mathrm{m}$ diameter) precoated with Matrigel (Wako Pure Chemical Industries, Ltd., Osaka) was placed. In addition, $200 \mu 1$ ( $2 \times 10^{5}$ cells) of the above-mentioned suspension of human fibrosarcoma HT-1080 cells treated at 37 or $42^{\circ} \mathrm{C}$ for $1 \mathrm{~h}$ in the presence of alkyl- and alkenylolides $(25 \mu \mathrm{M})$ was added and the plate was incubated for $3 \mathrm{~h}$. After incubation, the Chemotaxicell was removed, and after eliminating the supernatant and MatrixGel inside the Chemotaxicell, cells on the lower side of resin membrane of the Chemotaxicell were fixed and stained using DifQuik (Green Cross, Osaka). After the resin membrane was removed from the Chemotaxicell and fixed with the back surface on top in a slide glass, and the number of stained cells was counted under a microscope (13).

Statistics. Statistical differences were analyzed by Student's t-test.

\section{Results}

Carcinostatic effects of alkylolides and alkenylolides on shortterm (20 h) or long-term (72 h) cultures. Diverse species of alkyl-/alkenylolides were added to EAT cells, the samples were heated in a water bath at $37^{\circ} \mathrm{C}$ for $30 \mathrm{~min}$ and were maintained by sequential culture in a humidified atmosphere of $5 \% \mathrm{CO}_{2}$ in air at $37^{\circ} \mathrm{C}$ for $20 \mathrm{~h}$. The carcinostatic effects were measured using the WST-1 assay (Fig. 1A). Taking the cell viability of the control in the absence of alkyl-/alkenylolide as $100 \%$, the viability of the experimental samples at a dose of $100 \mu \mathrm{M}$ was evaluated. Hexadecane-16-olide (H16:0), pentadecane-15-olide (P15:0), and hexadecene-16olide $(\mathrm{H} 16: 1)$ were carcinostatic, giving a cell survival rate of $3.9 \pm 2.2 \%(\mathrm{P}<0.0001), 31.7 \pm 6.7(\mathrm{P}<0.0001)$, and 76.2 \pm 7.5 $(\mathrm{P}<0.0115)$ at $37^{\circ} \mathrm{C}$, respectively. The other samples, dodecane-12-olide (D12:0) and pentadecene-15-olide (P15:1) were almost ineffective.

To examine the effect of long-term exposure of alkyl-/ alkenylolides, the cells were further cultured at $37^{\circ} \mathrm{C}$ for $72 \mathrm{~h}$ and the carcinostatic activity was measured by WST-1 assay (Fig. 1A). At a dose of $50 \mu \mathrm{M}, \mathrm{H} 16: 0$ and P15:0 diminished the cell viability to $1.9 \pm 0.6 \%(\mathrm{P}<0.0001)$ and $23.6 \pm 4.3 \%$ $(\mathrm{P}<0.0001)$, respectively, corresponding to the values at $100 \mu \mathrm{M}$ in the culture for $20 \mathrm{~h}$, but the others exhibited slight activity or none. Treatment with H16:0, even at a dose as low as $25 \mu \mathrm{M}$, decreased the cell viability to $5.6 \pm 3.8 \%(\mathrm{P}<0.0001)$, whereas P15:0 was not effective at the same dose (almost inactive at $10 \mu \mathrm{M})$.

Carcinostatic activities of alkyl-/alkenylolides to the cells treated in the same manner as described above was also
A

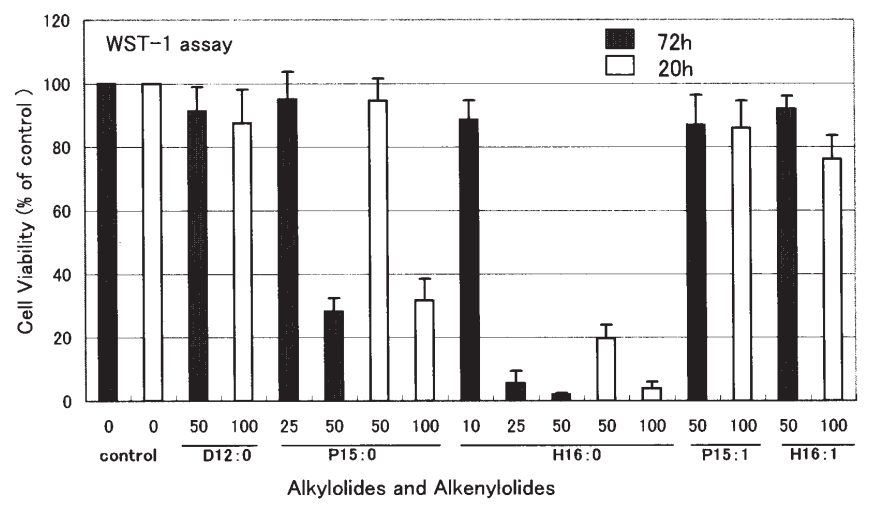

B

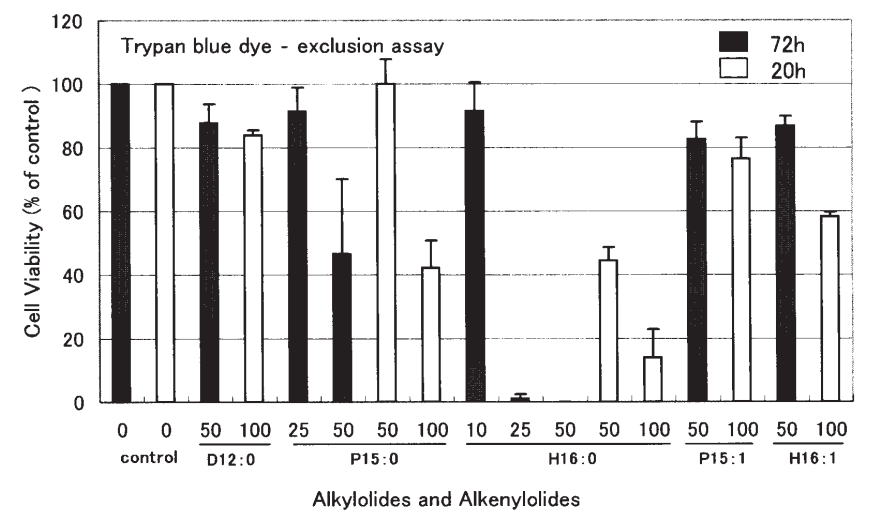

Figure 1. (A) Short- and long-term carcinostatic effects of alkylolides and alkenylolides on Ehrlich ascites tumor (EAT) cells as measured by mitochondrial dehydrogenase-based WST-1 assay. Cells were seeded at a density of $1 \times 10^{5}$ ( $20 \mathrm{~h}$ cultures) or $1 \times 10^{4}(72 \mathrm{~h}$ cultures) cells $/ \mathrm{ml}$, incubated in the presence of each alkyl-/alkenylolide at a dose of $10-100 \mu \mathrm{M}$ at $37^{\circ} \mathrm{C}$ for $30 \mathrm{~min}$ and further maintained by sequential culture at $37^{\circ} \mathrm{C}$ for 20 or $72 \mathrm{~h}$. Viability of the cells was measured by the absorption at $450 \mathrm{~nm}$ in WST-1 assay. The absorbance of cells treated in the absence of alkyl-/alkenylolide at $37^{\circ} \mathrm{C}$ was $1.432 \pm 0.437$ or $2.063 \pm 0.321$ (the control value), respectively. Data shown represent the means \pm SEM for quadruplicate measurements as percentages of the control value. (B) Short- and long-term carcinostatic effects of alkylolides and alkenylolides on the EAT cells as measured by trypan blue dye exclusion assay. Cells were treated as described in (A). Viability of the cells was evaluated by the trypan blue dye exclusion assay. The number of viable cells in the absence of alkyl-/alkenylolide at $37^{\circ} \mathrm{C}$ was $2.08 \pm 0.71 \times 10^{5}$ or $1.90 \times 10^{5}$ (the control value). Experimental values represent the means \pm SEM for triplicate measurements as percentages of the control value.

measured by trypan blue dye exclusion assay (Fig. 1B). It was shown that H16:0, P15:0, and H16:1 at a dose of $100 \mu \mathrm{M}$ diminished the cell viability to $14.0 \pm 8.9 \%(\mathrm{P}<0.0001)$, $42.2 \pm 8.5 \%(\mathrm{P}<0.0001)$, and $58.2 \pm 1.4 \%(\mathrm{P}<0.0001)$ versus that of the control, whereas P12:0 and H15:1 were not markedly carcinostatic.

Viability of the cell cultured for $72 \mathrm{~h}$ after the hyperthermic treatments was diminished by $\mathrm{H} 16: 0$ and P15:0 to $0.00 \%$ and $46.5 \pm 6.5 \%(\mathrm{P}<0.0001)$ at $50 \mu \mathrm{M}$, respectively, whereas the other alkyl-/alkenylolides were slightly or scarecely carcinostatic. Treatment with H16:0, even at a dose of $25 \mu \mathrm{M}$, decreased the cell viability to $1.0 \pm 1.2 \%(\mathrm{P}<0.0001)$. The results roughly coincided with those obtained by WST-1 assay. 
A

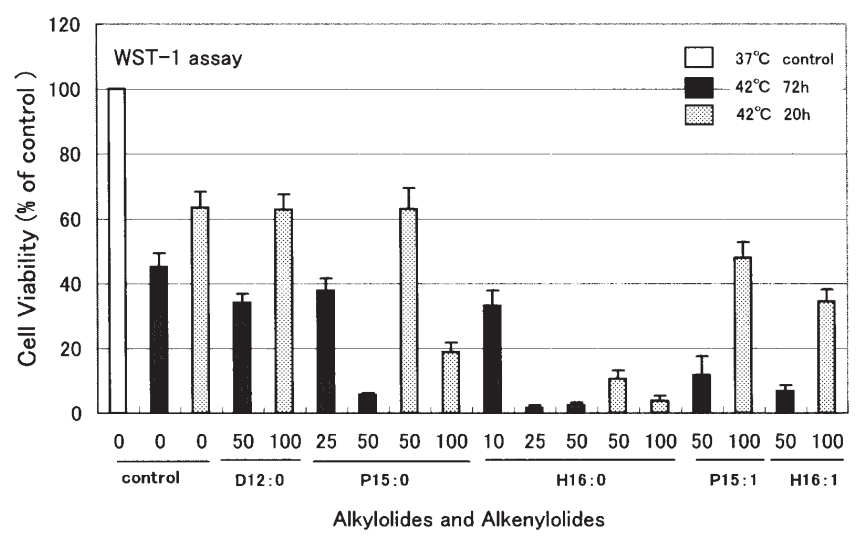

$\mathbf{B}$

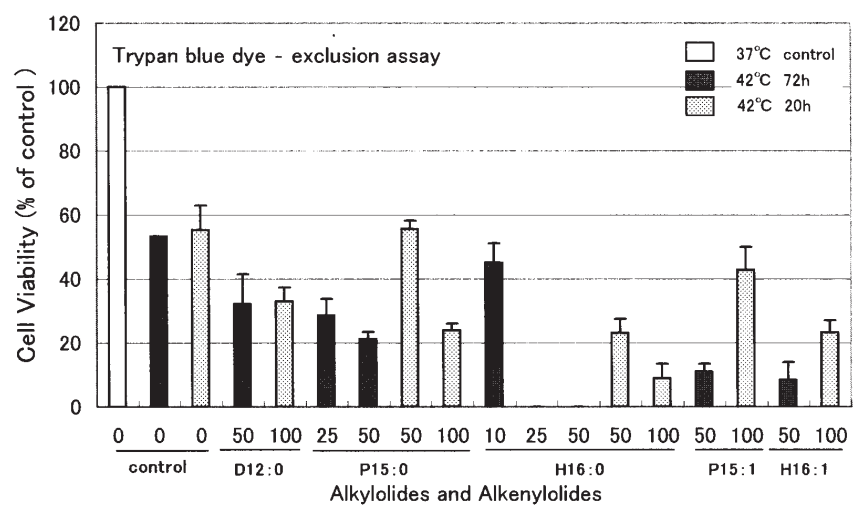

Figure 2. (A) Short- and long-term carcinostatic effects of alkylolides and alkenylolides on Ehrlich ascites tumor (EAT) cells in combination with hyperthermia (as measured by mitochondrial dehydrogenase-based WST-1 assay). Cells were seeded at a density of $1 \times 10^{5}$ (20 h cultures) or $1 \times 10^{4}(72 \mathrm{~h}$ cultures) cells $/ \mathrm{ml}$, incubated in the presence of each alkyl-/alkenylolide at a dose of $10-100 \mu \mathrm{M}$ at $42^{\circ} \mathrm{C}$ for $30 \mathrm{~min}$ and further maintained by sequential culture at $37^{\circ} \mathrm{C}$ for 20 or $72 \mathrm{~h}$. Viability of the cells was measured by the absorption at $450 \mathrm{~nm}$ in WST-1 assay. The absorbance of cells treated in the absence of alkyl-/alkenylolide at $37^{\circ} \mathrm{C}$ was $1.432 \pm 0.437$ or $2.063 \pm 0.321$ (the control value), respectively. Data shown represent the means \pm SEM for quadruplicate measurements as percentages of the control value. (B) Shortand long-term carcinostatic effects of alkylolides and alkenylolides on the EAT cells in combination with hyperthermia (as measured by trypan blue dye exclusion assay). Cells were treated as described in (A). Viability of the cells was evaluated by the trypan blue dye exclusion assay. The number of viable cells in the absence of alkyl-/alkenylolide at $37^{\circ} \mathrm{C}$ was $2.08 \pm 0.71 \times 10^{5}$ or $1.90 \times 10^{5}$ (the control value). Experimental values represent the means \pm SEM for triplicate measurements as percentages of the control value.

Effect of hyperthermia on carcinostatic effects of alkyl-/ alkenylolides. Viability of EAT cells cultured for $20 \mathrm{~h}$ after the treament at $42^{\circ} \mathrm{C}$ for $30 \mathrm{~min}$ was measured by WST- 1 assay (Fig. 2A). Hyperthermia alone at $42^{\circ} \mathrm{C}$ diminished the viability to $63.5 \pm 4.9 \%(\mathrm{P}<0.0001)$ versus that of the control at $37^{\circ} \mathrm{C}$. The viabilities at a dose of $100 \mu \mathrm{M}$ were in the following inverse order: H16:0 [6.0 $2.4 \%(\mathrm{P}<0.0001)]<$ $\mathrm{P} 15: 0[29.6 \pm 4.7 \%(\mathrm{P}<0.0001)]<\mathrm{H} 16: 1[54.2 \pm 8.4 \%$ $(\mathrm{P}<0.0001)]<\mathrm{P} 15: 1[75.4 \pm 6.6 \%(\mathrm{P}<0.0076)]$ indicating the carcinostasis exceeding over that due to hyperthermia alone $(100 \pm 7.3 \%)$. At a dose of $50 \mu \mathrm{M}$, only H16:0 diminished the cell viability to $16.7 \pm 3.9 \%(\mathrm{P}<0.0001)$ whereas $\mathrm{P} 15: 0$ was quite ineffective.

In long-term culture period for $72 \mathrm{~h}$ after the hyperthermic treatment, $\mathrm{H} 16: 0$ diminished the viability at a dose of $25 \mu \mathrm{M}$

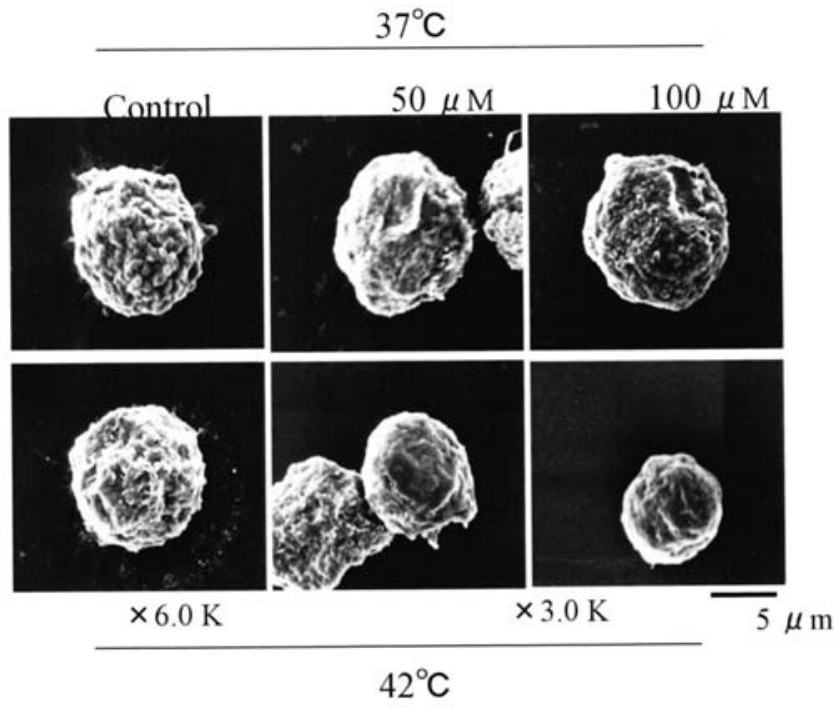

Figure 3. Scanning electron micrographs of EAT cells that were exposed to hexadecane-16-olide (H16:0). Cells were incubated in the presence of H16:0 at a dose of 50 or $100 \mu \mathrm{M}$ at 37 or $42^{\circ} \mathrm{C}$ for $30 \mathrm{~min}$ and maintained by sequential culture at $37^{\circ} \mathrm{C}$ for $20 \mathrm{~h}$, fixed and washed as conventionally conducted. Cells were fixed again with $1 \%$ osmic acid, washed and dehydrated. Cells were coated with ions after lyophilization, and cell shape was observed under a scanning electron microscope (x6.0 K, x3.0 K).

almost completely $[3.8 \pm 1.8 \%(\mathrm{P}<0.0001)]$, and was effective even at $10 \mu \mathrm{M}[73.4 \pm 10.6 \%(\mathrm{P}<0.0296)]$. $\mathrm{P} 15: 0$ decreased to $12.6 \pm 0.9 \%(\mathrm{P}<0.0001)$ at $50 \mu \mathrm{M}$, but was not effective at $25 \mu \mathrm{M}$, indicating a carcinostatic activity weaker than that of H16:0 also upon combination with hyperthermia. The alkenylolides $\mathrm{H} 16: 1$ and $\mathrm{P} 15: 1$ at $50 \mu \mathrm{M}$, non-effective at $37^{\circ} \mathrm{C}$, markedly reduced the viability to $15.1 \pm 4.0 \%(\mathrm{P}<0.0001)$ and $25.9 \pm 13.1 \%(\mathrm{P}<0.0001)$ versus that of the control, respectively. In contrast, D12:0 was the only examined compound that was not affected by hyperthermia at the same dose.

Carcinostatic effects of alkyl-/alkenylolides (at $100 \mu \mathrm{M}$ ) on the cells cultured for $20 \mathrm{~h}$ after hyperthermia at $42^{\circ} \mathrm{C}$, was measured by trypan blue dye exclusion assay (Fig. 2B). H16:0, P15:0, and H16:1 enhanced diminution of cell viability to $16.1 \pm 8.2 \%(\mathrm{P}<0.0001), 43.5 \pm 3.6 \%(\mathrm{P}<0.0001)$, and $42.0 \pm 6.7 \%(\mathrm{P}<0.0001)$ versus that $(100 \%)$ of hyperthermia alone, respectively. The others were scarcely carcinostatic at the same dose at $42^{\circ} \mathrm{C}$.

At 72-h culture after the treatment H16:0, P15:0, H16:1 and $\mathrm{H} 15: 1$ further diminished cell viability to $0.0 \%(\mathrm{P}<0.0001)$, $25.2 \pm 2.7 \%(\mathrm{P}<0.0001), 15.8 \pm 10.5 \%(\mathrm{P}<0.0001)$ and $20.6 \pm 4.5 \%(\mathrm{P}<0.0001)$ versus that $(100 \%)$ of hyperthermia alone, respectively. These results were approximately consistent with those by WST-1 assay.

Morphological changes in tumor cells observed by scanning electron microscopy. The carcinostatic effects were shown to be the greatest for H16:0 out of diverse samples, and morphological changes in EAT cells were therefore investigated using H16:0. Scanning electronic microscopy elucidated the morphological aspects (Fig. 3) of the cells treated with H16:0 at 37 or $42^{\circ} \mathrm{C}$ for $30 \mathrm{~min}$ and subsequently cultured for $20 \mathrm{~h}$. Hyperthermia at $42^{\circ} \mathrm{C}$ induced a drastic damage to the cell membrane surface including the disappearance of microvilli 


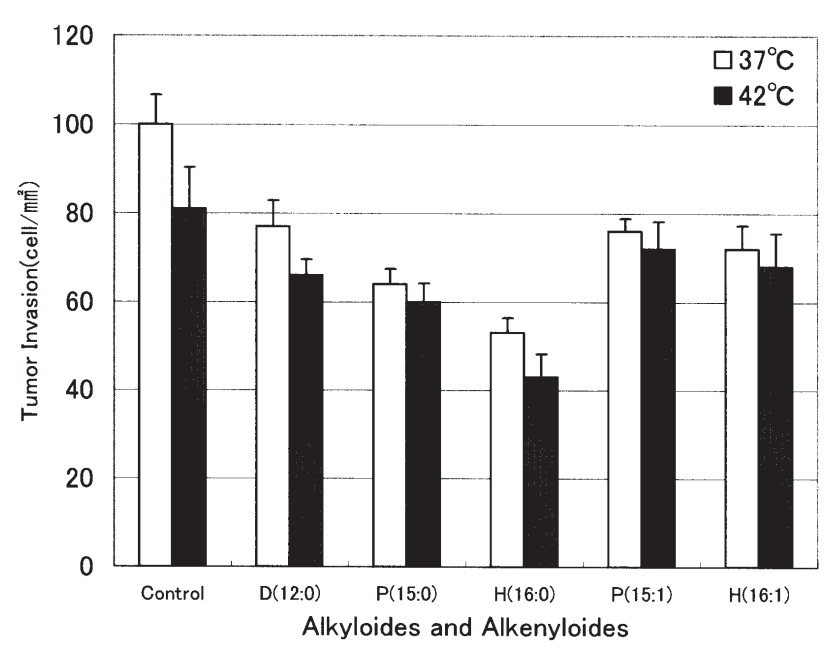

Figure 4. Inhibitory activity of alkylolides and alkenylolides against invasive activity of human fibrosarcoma HT-1080 cells. To a Chemotaxicell in a 24-well plate, $200 \mu 1$ of 5 or $20 \mu \mathrm{M}$ of alkyl-/alkenylolides and HT1080 cell suspension $\left(2 \times 10^{5}\right.$ cells $)$ were placed, and incubated for $1 \mathrm{~h}$. The cells that invaded through the reconstituted basement membrane were fixed and stained. The stained cells were counted under a microscope. Data shown are typical of three independent experiments that were conducted in triplicate; SD is represented by the bar.

in contrast to the intact aspects together with normal microvilli for untreated control. Furthermore, treatment with H16:0 induced cell destruction at $37^{\circ} \mathrm{C}$, and significantly enhanced markedly together with even cell fragmentation at $42^{\circ} \mathrm{C}$. Frequency of the above-mentioned abnormal cell morphology was more marked for the H16:0- and/or hyperthermiatreated cells than for the untreated control cells.

Effects on tumor cell invasion. The effect of diverse alkyl-/ alkenylolides on tumor cell (human fibrosarcoma HT-1080 cells) invasion is shown in Fig. 4. In non-additive (control) sample, 541 of total cells $\left(2 \times 10^{5}\right)$ passed through the porous resin membrane of the Chemotaxicell. Even the exposure of short-period $(3 \mathrm{~h})$ at low concentrations of $25 \mu \mathrm{M}$, invasion was suppressed by all alkyl-/alkenylolides in order of H16:0>P15:0>D12:0>H16:1>P15:1 in intensity. The suppressive activity was augmented in relation to the increase of their carbon atom, resulting the increase of their carcinostatic activity. H16:0 exhibited the highest suppressive activity, which reduced to $53.0 \pm 3.4 \%(\mathrm{P}<0.0001)$ of control value $(100 \%)$. The value of D12:0 exhibiting the lowest activity was 77.0 $\pm 5.8 \%(\mathrm{P}>0.0044)$. At $42^{\circ} \mathrm{C}, \mathrm{H} 16: 0$ and $\mathrm{P} 15: 0$ reduced to $52.9 \pm 6.5 \%(\mathrm{P}<0.0002)$ and $73.5 \pm 5.2 \%(\mathrm{P}<0.0179)$ versus that $(100 \%)$ of hyperthermia alone, respectively, but not other alkyl-/alkenylolides.

\section{Discussion}

Antitumor activity has been found in several macrocyclic lactones such as bryostatin and rhizoxin contained in various fungi (1-3). These natural compounds show a molecular weight of several hundred Da. In the present study, carcinostatic activity was detected in diverse chemically synthesized alkyl-/alkenylolides with molecular weights of 198-254 lower than those of the above-mentioned macrocyclic lactones. They inhibit the mitochondrial dehydrogenase activity and the

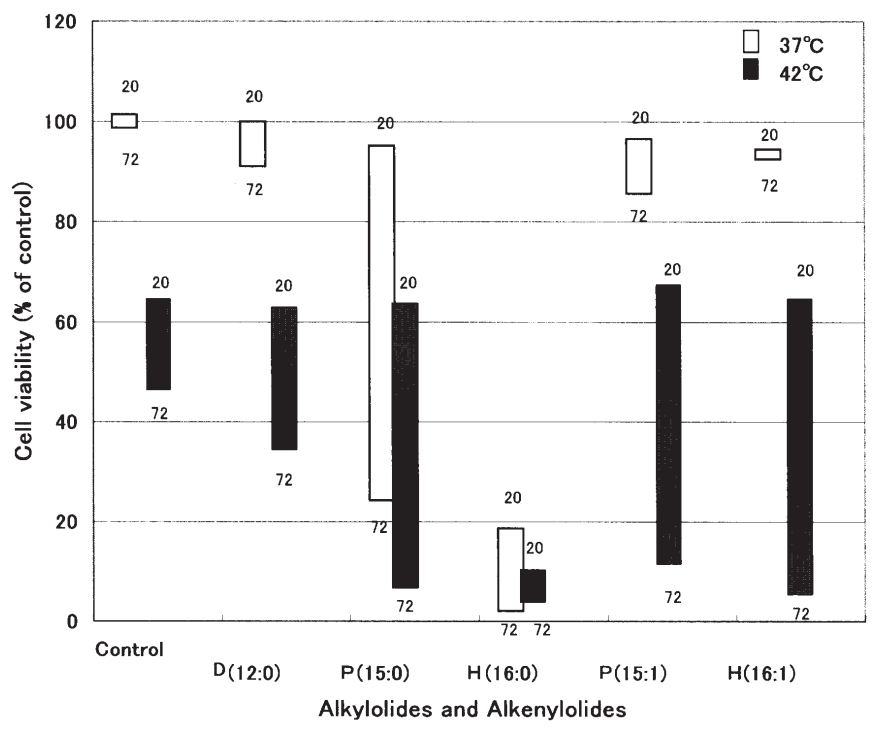

Figure 5. Effects of hyperthermia and sequential-culture period on the carcinostatic activities of diverse alkylolides and alkenylolides. The effects were calculated based on the values obtained at a dose of $50 \mu \mathrm{M}$ (see Fig. 1A and Fig. 3A). An open bar represents the value at $37^{\circ} \mathrm{C}$ and a closed bar that at $42^{\circ} \mathrm{C}$. The top and bottom termini of a bar exhibit the cell viability in sequential culture for periods of 20 and $72 \mathrm{~h}$, respectively. Longer bars show that the long-term culture promoted the cacinostatic activity more markedly than the short-term culture did. An open bar exhibits the value at $37^{\circ} \mathrm{C}$ and a closed bar exhibits that at $42^{\circ} \mathrm{C}$.

growth of Ehrlich ascites tumor cells strongly in the order of H16:0>P15:0>H16:1>P15:1>D12:0 (Figs.1 and 2). This order in degrees of carcinostatic activity was approximately consistent regardless of differences in bioassay methods, treatment periods ( 20 or $72 \mathrm{~h}$ ) and treatment temperatures (37 and $42^{\circ} \mathrm{C}$ ). Unexpectedly, it was found that: i) the carcinostatic activity of alkylolides diminishes along with decreasing number of carbon atoms. Chain-length shortening of H16:0 to P15:0 by only one methylene unit causes drastic attenuation of the carcinostatic ability. ii) saturated alkylolides such as H16:0 and P15:0 exceed over the corresponding unsaturated alkenylolides such as H16:1 and P15:1. These theories are in contrast to those applicable to fatty acids (14) and fatty alcohol (15).

Effects of hyperthermia and sequential culture period on the carcinostatic activities of diverse alkyl-/alkenylolides were illustrated based on the cell viabilities obtained at a dose of $50 \mu \mathrm{M}$ (Fig. 1A and Fig. 2A) (Fig. 5). The diverse alkyl-/alkenylolides can be classified as follows: i) H16:0 possesses the strongest carcinostatic activity regardless of hyperthermia and sequential long-term culture. ii) H15:0 enhances its activity more markedly by sequential long-term culture rather than by hyperthermia. iii) H12:0 scarcely enhances by either the treatment, indicating the smallest carcinostatic activity. iv) H16:1 and H15:1 enhance their activity only by dual consecutive treatments of sequential long-term culture after hyperthermia, but do not enhance by a single treatment of long-term culture or hyperthermia.

Inhibition of invasion of tumor cells using a blood vessel model in vitro is considered to reflect prevention of permeation to vein in the first step of metastasis (13). Alkyl-/ alkenylolides could inhibit invasive action of human fibrosarcoma HT1080 cells even after the short-term exposure at 
$25 \mu \mathrm{M}$ for $3 \mathrm{~h}$ not diminishing cell viability. The inhibitory activity is elevated according to the increase of their carbon atoms. Accordingly, H16:0 exhibited the highest inhibitory activity as well as the highest carcinostatic activity. These effects are promoted by hyperthermia.

When mechanisms of the antitumor effects are considered, natural macrocyclic lactones, such as bryostatin and rhizoxin may be due to stimulating the transcription of cyclooxygenase-2 (16), activating protein kinase C (17), and inhibiting cell proliferation (16), the mitosis in cells and tubulin polymerization (18).

The authors have regarded intracellular permeation of alkyl-/alkenylolides as a cause of cytotoxic actions. Fatty acids (19), hydroxy fatty acids (10), and fatty alcohols (15) that are incorporated into the cells (detected by gas-liquid chromatography) inhibit DNA synthesis $(19,15)$, mitochondrial dehydrogenase activity and growth of tumor cells (10). $\delta$ alkyllactone is also incorporated into tumor cells (23). However, the alkyl-/alkenylolides used in the present study could not be detected in the cells, whereas they were detected in the extracellular liquid. However, they could not be detected in the cells. Therefore, their carcinostatic effects may be due to their surface activity towards the cell membrane. Hyperthermia is known to inhibit the DNA synthesis in tumor cells (20-22) and to diminish the tumor cell viability by combination with anti-cancer agents. As morphologically observed by SEM, the injury of cell membrane surface and the deformation of cells can be regarded as typical symptoms indicative of cytotoxic action of H16:0 and hyperthermia.

Of the new macrocyclic lactones, hexadecane-16-olide (H16:0) exhibits the most carcinostatic activity and tumoricidal action; the activity of hexadecen-16-olide (H16:1) is considerably enhanced by hyperthermia and can destruct the tumor-tissue specifically by means of hyperthermia locally applied to the target tumor.

Thus, some alkyl-/alkenylolides are more attractive as potent antitumor regimens in terms of reduction of both the side-effect towards the normal tissues and the lethal metastasis occurring secondarily after application of some conventional cytotoxic anticancer agents.

\section{Acknowledgements}

We would like to thank Mr. Kunihiko Kinoshita, the Managing director and Dr Nobuhiko Ito, and Mr. Hiroshi Tsuji (Soda Aromatic Co., Ltd.) for synthesizing and supplying diverse alkyl-/alkenylolides, macrocyclic lactones, Ms. Haruko Mimura for her technical assistance, and Ms. Naoko Yoshimura for supporting the preparation of our manuscript.

\section{References}

1. Pettit GR, Herald CL, Doubek DL, Herald DL, Arnold E and Clardy J: Isolation and structure of bryostatin-1. J Am Chem Soc 104: 6846-6848, 1982.

2. Iwasaki S, Kobayashi H, Furukawa J, Namikoshi M, Okuda S, Sato Z, Matsuda I and Noda T: Studies on macrocyclic lactone antibiotics. VII. Structure of a phytotoxin 'Rhizoxin' produced by Rhizopus chinensis. J Antibiot 37: 354-362, 1984.

3. Kiyoto S, Kawai Y, Kawakita T, Kino E, Okuhara M, Uchida I, Kino E, Okuhara M, Uchida I, Tanaka H, Hashimoto M, Terano $\mathrm{H}$ and Kohsaka M: A new antitumor complex, WF-1360 A, B, C, D, E and F. J Antibiot 39: 762-772, 1986.
4. Gebbia V, Citarrella P, Miserendino V, Valenza R, Borsellino N, Pesta A, Pettit R and May S: The effects of the macrocyclic lactone bryostatin-1 on leukemic cells in vitro. Tumori 30: 167-171, 1992.

5. Schuchter LM, Esa AH, May S, Laulis MK, Pettit GR and Hess AD: Successful treatment of murine melanoma with bryostatin-1. Cancer Res 51: 682-687, 1991.

6. Harris M: Criteria of viability in heat-treated cells. Expt Cell Res 44: 658-660, 1966.

7. Palzer RJ and Heidelberger C: Studies on the quantitative biology of hyperthermic killing of HeLa cells. Cancer Res 33: 415-421, 1973.

8. Kageyama K, Onoyama Y, Otani S, Kimura M, Matsui-Yuasa I, Nagao N and Miwa N: Promotive action of acylated ascorbate on cellular DNA synthesis and growth at low doses in contrast to inhibitory action at high doses or upon combination with hyperthermia. J Cancer Res Clin Oncol 122: 41-44, 1996.

9. Ishiyama M, Shiga M, Sakamoto K, Mizoguchi M and PinGang He: A new sulfonated tetrazolium salt that produces a highly water-soluble formazan dye. Chem Pharm Bull 41: 1118-1122, 1993.

10. Kusumoto K, Kageyama K, Tanaka H, Kogawa H and Miwa N: Enhancement of carcinostatic activity of omega-hydroxy fatty acids by their esterification through increased uptake into tumor cells. Oncol Rep 11: 857-861, 2004.

11. Gray JG, Monaco AP, Wood ML and Russell PS: Study on Heterologeus anti-lymphocyte serum in mice. J Immunol 96: 217-228, 1966.

12. Anderson TF: Techniques for the preservation of threedimensional structure in preparing specimens for the electron microscopes. Trans NY Acad Sci 13: 130-134, 1951.

13. Albini A, Iwamoto Y, Kleinman HK, Martin GR, Aaronson SA, Kozlowski JM and McEwan RN: A rapid in vitro assay for quantitatating the invasive potential of tumor cells. Cancer Res 47: 3239-3245, 1987.

14. Kageyama K, Onoyama Y, Nakanishi M, Matsui-Yuasa I, Otani S and Morisawa S: Synergistic inhibition of DNA synthesis in Ehrlich ascites tumour cells by a combination of unsaturated fatty acids and hyperthermia. J Appl Toxcol 9: 1-4, 1989.

15. Takada Y, Kageyama K, Yamada R, Onoyama Y, Nakajima T, Hosono M and Miwa N: Correlation of DNA synthesis-inhibiting activity and the transmembrane permeation into tumor cells by unsaturated or saturated fatty alcohols of graded chain-lenghth upon hyperthermia. Oncol Rep 8: 547-551, 2001.

16. De Lorenzo MS, Yamaguchi K, Subbaramaiah K and Dannenberg AJ: Bryostatin-1 stimulates the transcription of cyclooxygenase-2: evidence for an activator protein-1-dependent mechanism. Clin Cancer Res 9: 5036-5043, 2003.

17. Kraft AS, Smith JB and Berkow RL: Bryostatin, an activator of the calcium phospholipid-dependent protein kinase blocks phorbol ester-induced differenciation human promyelocytic leukemia cells HL-60. Proc Natl Acad Sci USA 83: 1334-1338, 1986.

18. Takahashi M, Iwasaki S, Kobayashi H, Okuda S, Murai T and Sato Y: Rhizoxin binding to tubulin at the maytansine-binding site. Biochem Biophys Acta 926: 215-223, 1987.

19. Kageyama K, Yamada R, Otani S, Onoyama Y, Yano I, Yamaguchi W, Yamaguchi Y, Kogawa H, Nagao N and Miwa N: Cytotoxicity of docosahexaenoic acid and eicosajpentaenoic acid in tumor cells and the dependence on binding to serum proteins and incorporation into intracellular lipids. Oncol Rep 7: 79-83, 2000.

20. Mondovi B, Finazzi AA, Rotillo G, Strom R, Moricca G and Rossi FA: The biochemical mechanism of selective heat sensitivity of cancer cells. II. Studies on nucleic acids and protein synthesis. Eur J Cancer 5: 137-146, 1969.

21. Henle KJ and Leeper DB: Effect of hyperthermia $\left(45^{\circ} \mathrm{C}\right)$ on macromolecular synthesis in Chinese hamster ovary cells. Cancer Res 39: 2665-2674, 1979.

22. Kageyama K, Onoyama Y, Kimura M, Yamazaki H and Miwa N: Enhanced inhibition of DNA synthesis and release of membrane phospholipids in tumour cells treated with a combination of acylated asorbate and hyperthermia. Int J Hyperthermia 7: 85-91, 1991.

23. Tanaka H, Kageyama K, Yoshimura N, Asada R, Kusumoto K and Miwa N: Anti-tumor and anti-invasive effects of diverse delta-alkyllactone: Dependence on molecular side-chain length, action period and intracellular uptake. Life Sciences 80: 851$855,2007$. 